\title{
Erratum to: Systemic Gene Delivery Protects the Photoreceptors in the Retinal Degeneration Slow Mouse
}

Tim Sullivan - Tonia S. Rex

Published online: 9 May 2012

(C) Springer Science+Business Media, LLC 2012

Erratum to: Neurochem Res (2011) 36:613-618

DOI 10.1007/s11064-010-0272-6

The name of Kishore Kodali has been removed from the list of authors, at Dr. Kodali's request. The complete author list should be considered as it appears above.

The online version of the original article can be found under doi: 10.1007/s11064-010-0272-6.

T. Sullivan · T. S. Rex $(\bowtie)$

Department of Ophthalmology, Hamilton Eye Institute,

University of Tennessee Health Science Center,

930 Madison Ave., Ste. 731, Memphis, TN 38163, USA

e-mail: trex@uthsc.edu 